\title{
Obtención de ladrillos cara vista a partir de cenizas volantes de la Central Térmica del Narcea (Asturias)
}

\author{
Bare face red-brown bricks manufactured with fly ash from the \\ Narcea (Asturias) Coal Power Plant
}

Fecha de recepción: 20-VII-98

Fecha de aceptación: 11- I- 99
G. AYESTA, M.P.GARCÍA, F. BLANCOy J. AYALA Dpto. de Ciencia de los Materiales. Escuela de Minas

Oviedo(ESPAÑA)

\section{RESUMEN}

Se caracterizan las cenizas volantes de la Central Térmica del Narcea (Asturias) para determinar su utilización como materia príma en la obtención de ladrillos cara vista.

\begin{abstract}
El moldeo correcto de una pieza cerámica exige trabajar una pasta con una adecuada plasticidad, para ello se investiga cuál ha de ser la composición óptima de la misma, en cuanto a: humedad, cantidad de lubricante (talco) y de ligante (dextrina blanca). El conformado de las piezas o ladrillos se realiza por prensado, utilizando distintos valores de presión, así como la temperatura de cocción, una vez establecida la velocidad de enfriamiento. Finalmente, las piezas cocidas se someten a los ensayos exigidos por la Norma Básica de Edificación, para ver si cumplen las especificaciones requeridas en cuanto a: Absorción de agua, Succión, Contracción, Heladicidad, Eflorescencia y Resistencia a la compresión.
\end{abstract}

\begin{abstract}
SUMMARY
Fly ash, from the Coal Power Plant of Narcea (Asturias), has been used to determine its possible use as a raw material in the bare face red-brown brick manufacture.

The correct mould of a ceramic material demands a paste with an adequate plasticity. So, the optimum compositions of humidity, lubricant (talc) and binder (white dextrin) have been investigated. The samples were made by compressing paste into a mould using varying values of pressure and boiling temperature once the cooling speed had been established. Finally, the cooked pieces were submitted to trials demanded by the Basic Construction Norm, to see if they met the required specifications concerning Water Absorption, Suction, Contraction, Resistance to Freezing, Efflorescence and Compressive Strength.
\end{abstract}

\section{INTRODUCCIÓN}

Actualmente, muchos procesos tecnológicos llevan consigo la producción de una serie de subproductos que suponen una gran inversión económica para su manipulación, lo que ha llevado a los técnicos a crear y conseguir aplicaciones para los mismos que los hagan rentables.

\section{INTRODUCTION}

Currently, many technological processes carry with them the production of a series of by-products which pose as a great economic investment. The properties, and hence applications, of the by-product must be researched and studied by technical personnel. 
En los procesos de generación de energía eléctrica en las centrales térmicas que consumen combustibles sólidos se recogen unos productos, denominados cenizas volantes, que por sus características y propiedades pueden utilizarse como material de construcción, bien sustituyendo al cemento o como adición a procesos establecidos de construcción (1) (2) (3) (4).

Las cenizas volantes constituyen la fracción mineral, no quemada, de los carbones y representa el residuo de las centrales térmicas que queman carbón pulverizado, cuya parte más importante es arrastrada por la corriente de gases de combustión y eliminada de ellos en los precipitadores mecánicos y electrostáticos.

Los ladrillos cara vista, que usualmente se fabrican a partir de una mezcla de arcillas plásticas y arena, que actúa como desgrasante, pueden ser fabricados usando cenizas volantes (5) (6). Generalmente se sustituye parte de la arcilla plástica por las cenizas. Sin embargo, en este trabajo se van a utilizar las cenizas volantes como materia prima única para la elaboración de ladrillos, confiriéndoles a éstos unas características mínimas admisibles de mercado. De esta forma se da aprovechamiento a una parte de los millones de toneladas de residuos que se acumulan en las proximidades de las fábricas que los generan y que provocan, con el transcurso del tiempo, un problema de almacenamiento, de espacio físico y medio ambiental.

Asimismo, mediante la reutilización de estas materias se consigue prorrogar la vida de los recursos naturales, como las arcillas, para las generaciones venideras y detener la destrucción del paisaje.

\section{CARACTERIZACIÓN DE LAS CENIZAS VOLANTES}

La caracterización de las cenizas volantes y su uniformidad con el tiempo permiten definir los parámetros de su calidad, pues una condición necesaria para cualquier materia prima es que sus propiedades no varíen, para evitar perjuicios en los procesos de fabricación a los que se van a destinar.

Las cenizas utilizadas en este trabajo proceden de la Central Térmica del Narcea que quema antracitas de la cuenca del Narcea, originando su combustión una producción anual de $240.000 \mathrm{t}$.

\subsection{Análisis químico}

El análisis químico efectuado a las cenizas volantes ha sido realizado por espectroscopia de absorción atómica de llama, los valores obtenidos se recogen en
In the process of electrical energy generation, in a power plant, finely ground coal is burnt and the product from the combustion gases in the mechanical and electrostatic precipitators is collected, this product is known as fly ash. Therefore, due to its characteristics and properties, it can be used as a construction material by substituting it for cement or as an addition to the established process (1) (2) (3) (4).

Fly ashes constitute the mineral fraction, not burnt, of coals and represents the residue of Power plant that burn pulverized coal, whose more important part is dragged by the current of combustion gases and eliminated them in the mechanical and electrostatic precipitator.

The bare face red-brown brick, that commonly are manufactured from a mixture of plastic clays and sand, they can be manufactured using fly ashes (5) (6). Generally, part of the plastic clay is substituted by fly ashes. However, in this work fly ash is used as the only one raw material for brick elaboration. These bricks had the minimal characteristics of market.

Used in this way, it provides a use for some of the millions of tonnes of residue that are produced in power plants that, with time, cause a storage problem of both physical space and environmental means.

In addition, through the reutilization of these byproducts, the lives of the natural resources, such as clay, are extended and the destruction of the landscape is minimised.

\section{CHARACTERIZATION OF THE FLY ASH}

The characterization of the fly ash and its uniformity with time define the parameters of its quality since a necessary condition for any raw material is that its properties do not vary to avoid prejudices in the manufacturing process.

The ashes used in this work were produced at the Narcea Coal Power Plant which burns anthracites of the Narcea basin with an annual production of $240.000 t$.

\subsection{Chemical analysis}

The chemical analysis of the fly ash has been deduced by atomic absorption spectroscopy and the obtained results can be seen in table 1. Fly ash was melt with a 
la tabla 1. Las cenizas se fundieron con una mezcla de ácido bórico y carbonato de litio 1:1 en un horno a $950^{\circ} \mathrm{C}$. Posteriormente, se disolvió la muestra añadiendo agua y $5 \mathrm{ml}$ de ácido nítrico concentrado. Cabe destacar que la suma de sílice y de alúmina se sitúa entorno al $80 \%$ y que el contenido de óxido de hierro es elevado.

\subsection{Composición mineralógica}

La estructura cristalina de las cenizas volantes se ha determinado utilizando la técnica de difracción de Rayos X. La figura 1 pone de manifiesto que la única fase cristalina es cuarzo y en pequeña proporción. No se detecta la presencia ni de silimanita ni mullita, pero si la existencia de la denominada banda difusa, la cual es un indicativo de la presencia de una fase vítrea. Para las cenizas bajas en calcio ésta se sitúa en el intervalo $2 \phi=21-26^{\circ}$, para la radiación $\mathrm{K} \alpha 1,54 \mathrm{~A}$, mientras que para las altas en calcio la presentan en el intervalo $2 \phi=30-34^{\circ}$. Las cenizas de la Central Térmica del Narcea la muestran en el entorno de los $25^{\circ}$.

\subsection{Análisis granulométrico}

La granulometría determinada por tamizado en húmedo da como resultados que: la fracción inferior a $45 \mu \mathrm{m}$ representa el $85 \%$ en peso, y la fracción inferior a $90 \mu \mathrm{m}$ el $96 \%$.

La distribución granulométrica para la fracción menor de $45 \mu \mathrm{m}$ se determinó con el Foto Sedimentador Lumosed, la cual se muestra en la figura 2, y de la que se deduce que el tamaño medio de partícula es de $15 \mu \mathrm{m}$.

\subsection{Análisis Morfológico.}

Las cenizas volantes, por no ser un compuesto puro no presentan la transformación sólido-líquido a una temperatura constante, sino que dicha transformación tiene lugar de una manera gradual, y la fusión se realiza en un intervalo de temperaturas.

La observación al microscopio de pastillas formadas mediante la compactación de cenizas por prensado en seco, pone de manifiesto la naturaleza vítrea de las mismas, así como su morfología esférica, independientemente de su tamaño, tal como se muestra en la figura 3, realizada a 200 aumentos con un microscopio de mesa invertida Nikon Epiphot.

En la figura 4 obtenida con un microscopio electrónico de barrido se aprecia las características indicadas, así como una plerosfera, que es una partícula hueca que tiene en su interior otras partículas esféricas (7). mixture of $1: 1$ boric acid and lithium carbonate in a furnace at $950^{\circ} \mathrm{C}$. Then, the crucible was put into a beaker which contains deionized water and $5 \mathrm{ml}$ of concentrate nitric acid to obtain the sample solution It is important to emphasize that nearly $80 \%$ of the fly ash is consisted of silica and alumina whilst the amount of iron oxide is also relatively high.

\subsection{Mineral composition}

The crystalline structure of the fly ash has been determined using the technique of XRD. Figure 1 shows that the only crystalline phase present is quartz, and in small proportion. Neither sillimanite nor mullite were detected and due to the presence of a single peak in the XRD it can be stated that the majority of the material is vitreous. For the ashes low in calcium this is found in the interval $2 \phi=21-26^{\circ}$ whilst when the calcium level is high the interval is $2 \phi=30^{\circ}-34^{\circ}$. The ashes of the Narcea Coal Power Plant show it to be approximately $25^{\circ}$.

\subsection{Size analysis}

The grain size is determined by wet sifting and states that $85 \%$ by weight has a grain size lower than $45 \mu \mathrm{m}$ and $96 \%$ lower than $90 \mu \mathrm{m}$.

The grain size distribution for the fraction lower than $45 \mu \mathrm{m}$ was determined with the Photo Sedimentador, Lumosed, see figure 2, and from which it was deduced that the mean particle size is $15 \mu \mathrm{m}$.

\subsection{Morphology analysis}

The fly ash does not present the solid - liquid transformation at a constant temperature, because fly ash is not a pure compound but such transformation takes place in a gradual way, and the fusion is accomplished in an interval of temperatures.

The microscope observation of the tablets, formed by pressing in dry fly ash, shows the vitreous nature of the same, as well as its spherical morphology, independently of its size. A Nikon Epiphot microscope accomplished to 200 increases was used, figure 3.

In the figure 4 obtained with an electronic microscope (SEM) is appreciated the indicated characteristics, as well as a plerosphere, that it is a hole particle which has in its interior other spherical particles (7). 
TABLA 1 (TABLE 1)

Composición química de las cenizas volantes

(Chemical composition of the fly ash)

\begin{tabular}{|c|c|c|c|c|c|c|c|c|c|}
\hline & $\begin{array}{r}\mathrm{P} . \mathrm{C} \\
(\%)\end{array}$ & $\begin{array}{c}\mathrm{Al}_{2} \mathrm{O}_{3} \\
(\%)\end{array}$ & $\begin{array}{c}\mathrm{SiO}_{2} \\
(\%)\end{array}$ & $\begin{array}{c}\mathrm{Fe}_{2} \mathrm{O}_{3} \\
(\%)\end{array}$ & $\begin{array}{c}\mathrm{CaO} \\
(\%)\end{array}$ & $\begin{array}{c}\mathrm{MgO} \\
(\%)\end{array}$ & $\begin{array}{c}\mathrm{Na}_{2} \mathrm{O} \\
(\%)\end{array}$ & $\begin{array}{c}\mathrm{K}_{2} \mathrm{O} \\
(\%)\end{array}$ & $\begin{array}{c}\mathrm{TiO}_{2} \\
(\%)\end{array}$ \\
\hline $\begin{array}{c}\text { Cenizas } \\
\text { volantes } \\
\text { (Fly ash })\end{array}$ & 2,45 & 24,6 & 54,5 & 6,42 & 4,16 & 2,07 & 0,43 & 3,45 & 1,07 \\
\hline
\end{tabular}

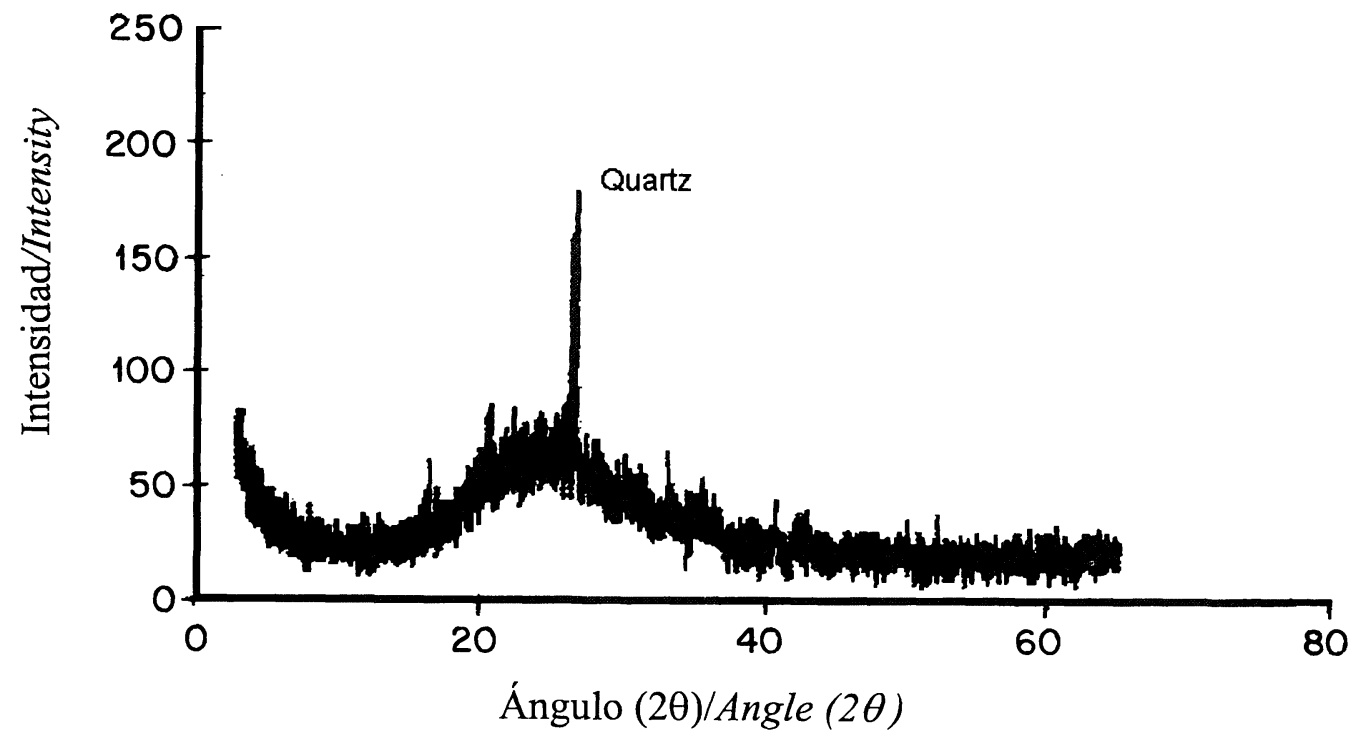

Figura 1.- Difractograma de las cenizas volantes.

Figure 1.- Diffractogram of fly ash.

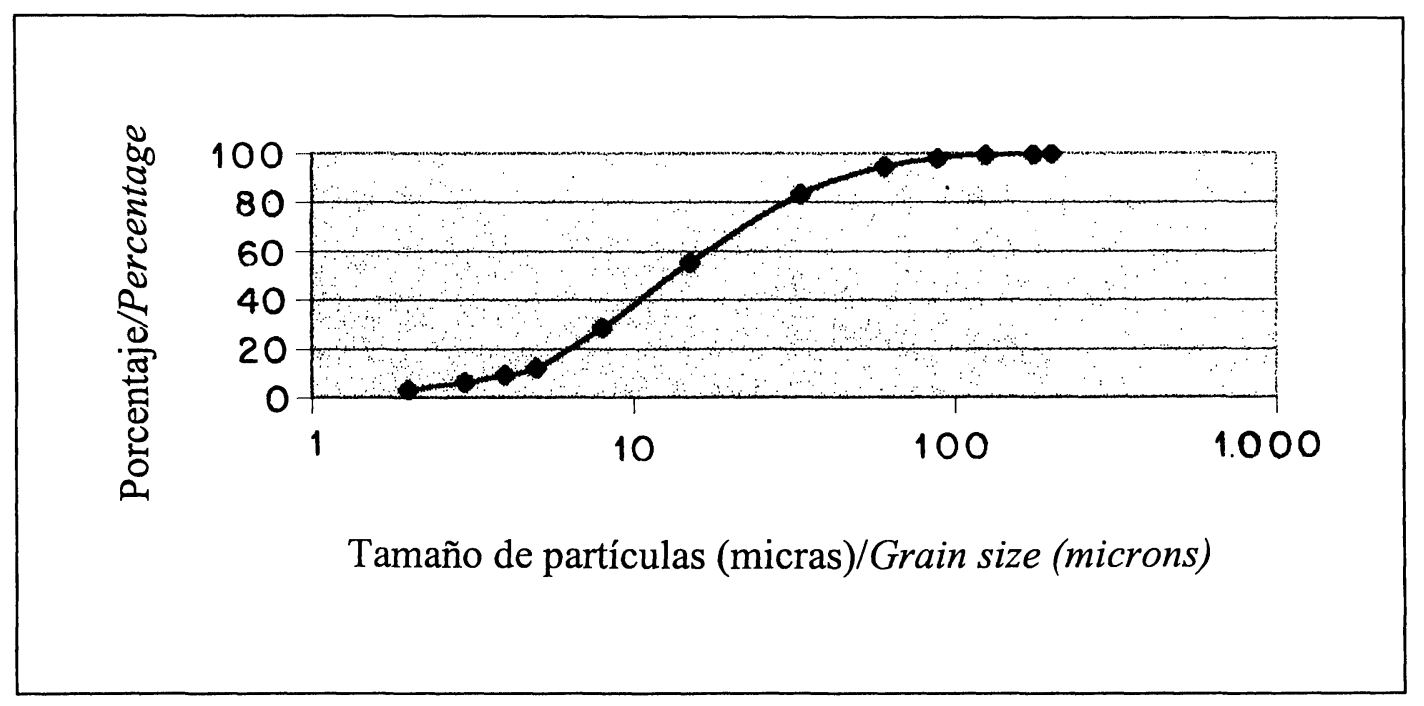

Figura 2.- Distribución granulométrica.

Figure 2.- Granulometry distribution. 


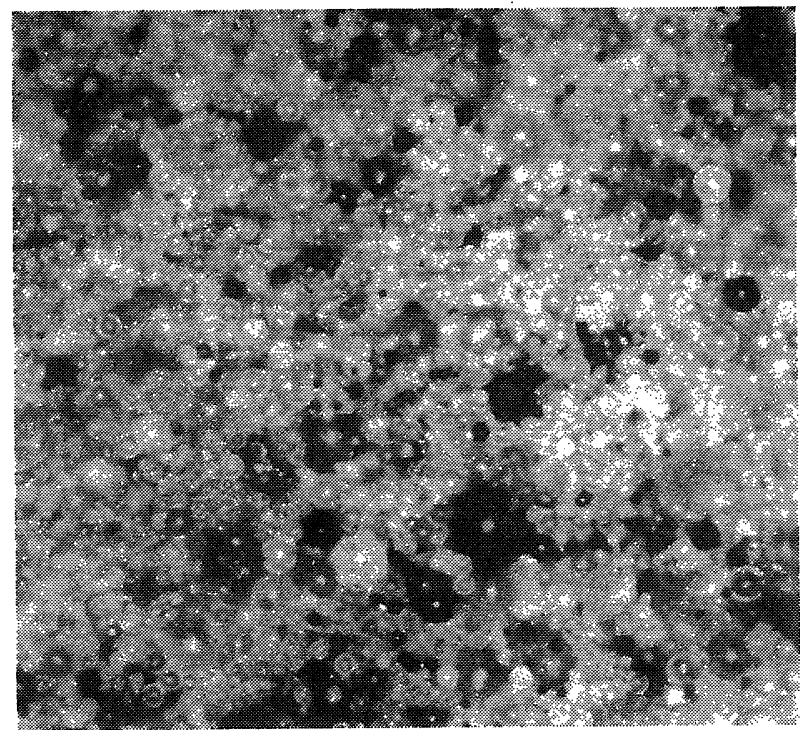

Figura 3.- Visión microscópica de las cenizas volantes.

Figure 3.- Microscopic photo of fly ash.

\subsection{Fusibilidad}

El conocimiento del intervalo de fusión es una característica importante, ya que da información sobre la temperatura necesaria para la cocción de las piezas. La fase líquida no aparece a una determinada temperatura, la fluidez va aumentando con la temperătura $\mathrm{y}$, finalmente, se produce el estado líquido.

Los ensayos de temperatura de fusión se han realizado con el equipo AF-600 de LECO, específicamente diseñado para determinar la fusibilidad de las cenizas de carbón. El equipo proporciona los resultados automáticamente una vez preparados los conos y colocados sobre la bandeja giratoria.

La refractariedad media, tomada como temperatura de reblandecimiento, es de $1.295^{\circ} \mathrm{C}$.

\section{PROCESO DE FABRICACIÓN DE LAS PIEZAS}

El diagrama de flujo, que constituye la figura 5, muestra la secuencia de operaciones realizadas en la elaboración de las piezas cerámicas (8) (9).

\subsection{Preparación de la pasta}

Las cenizas volantes, tal y como se reciben de la central térmica, son humedecidas con agua en una proporción del $6 \%$ en peso, para, posteriormente, adicionar dextrina blanca como ligante en una cantidad

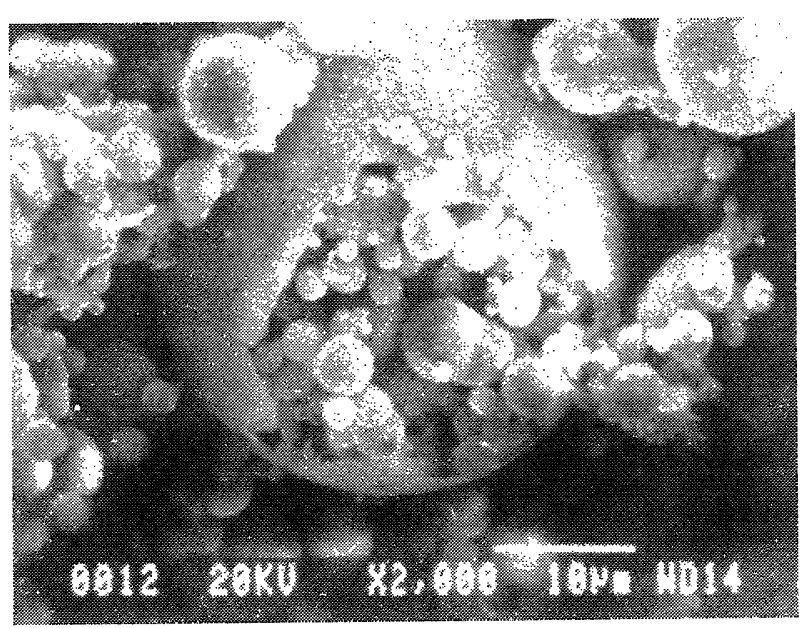

Figura 4.- SEM de las cenizas volantes

Figure 4.- SEM of fly ash.

\subsection{Fusibility}

The knowledge of the melting range gives very good information for the baking temperature of the ceramic pieces. It is known that the liquid phase does not appear at a fixed temperature, fluidity increases progressively over a certain temperature range. Finally, the liquid state is produced.

To determine the melting range the LECO AF-600, specially designed to determine the fusibility of coal ashes, was used. This equipment provides the results automatically once the prepared cones are put on the revolving tray.

The mean refractoriness is taken at a partial softness at a temperature of $1.295^{\circ} \mathrm{C}$.

\section{MANUFACTURING PROCESS OF THE PIECES}

The flow graph, shown in figure 5, shows the sequence of operations for the manufacture of the ceramic pieces (8) (9).

\subsection{Preparation of the paste}

The fly ash, as received from the power plant, is wet with $6 \%$ weight of water. It must then be mixed with $1 \%$ by weight of white dextrin (a binder) and talc ( $a$ lubricant) in the same proportion. This mixture must 


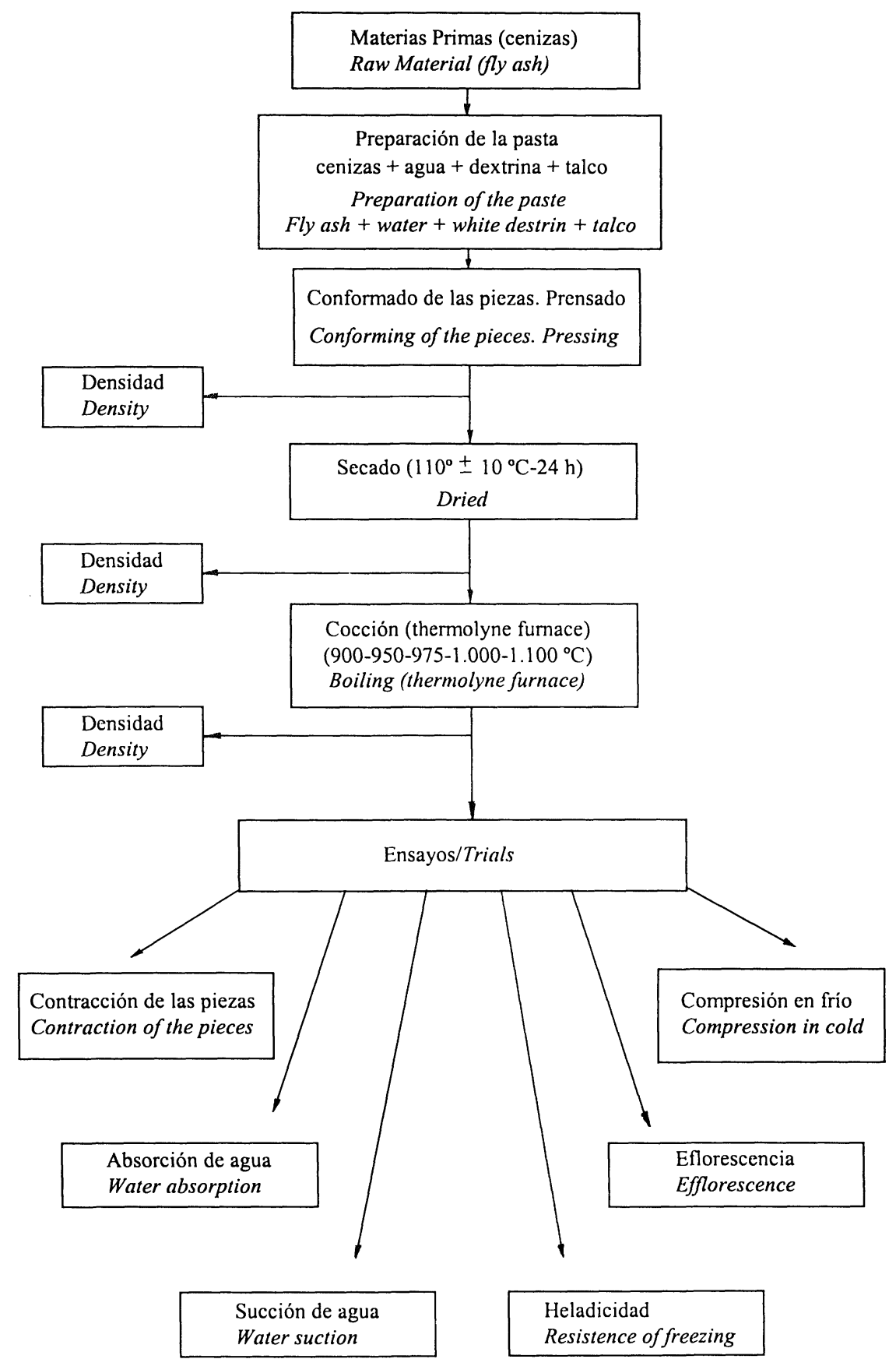

Figura 5.- Diagrama de flujo del proceso.

Figure 5.- Flow graph of the process.

del $1 \%$ en peso y talco como lubricante en la misma proporción. Esta mezcla se homogeneiza mediante amasado.

\subsection{Conformado de las piezas}

Las piezas se han conformada por prensado, operación realizada por acción de una compresión mecánica de la pasta sobre el molde. La prensa utiiizada es una prensa be homogenised by kneading until an adequate plasticity is obtained.

\subsection{Conforming of the pieces}

The pieces were formed by pressing, accomplished by the action of a mechanical compression of the paste in the mould. The press used was a hydraulic uniaxil 
hidráulica de laboratorio de prensado uniaxil, provista de moldes cilíndricos de $40 \mathrm{~mm}$ de diámetro.

La presión de prensado se usó como parámetro variable, y los valores utilizados han sido: $15,6 \mathrm{MPa}$, $31,2 \mathrm{MPa}, 46,8 \mathrm{MPa}$ y $62,4 \mathrm{MPa}$.

Una vez, conformadas las piezas se determinó la densidad y el valor medio obtenido para todas ellas es de $1,7 \mathrm{~g} /$ c.c.

\subsection{Secado}

La operación de secado se realiza en una estufa a una temperatura de $110 \pm 10^{\circ} \mathrm{C}$ durante 24 horas para la eliminación del agua del material hasta alcanzar una humedad que esté en equilibrio con el aire que lo rodea.

\subsection{Cocción}

Es la operación más importante de todo el proceso de fabricación, pues es aquí donde se pone de manifiesto la bondad de las etapas anteriores y si el producto acabado posee las propiedades requeridas por las Normas.

En la cocción intervienen una serie de parámetros, como son: temperatura máxima de cocción, que, de acuerdo con la bibliografía, los valores utilizados son: $900{ }^{\circ} \mathrm{C}, 9500^{\circ} \mathrm{C}, 975^{\circ} \mathrm{C}, 1.000^{\circ} \mathrm{C}$ y $1.100^{\circ} \mathrm{C}$; el tiempo de permanencia a la temperatura elegida, 2 horas, siendo la atmósfera del horno, oxidante; la velocidad de calentamiento, $2^{\circ} \mathrm{C} / \mathrm{min}$ y la de enfriamiento, $1^{\circ} \mathrm{C} / \mathrm{min}$.

\section{ENSAYOS REALIZADOS Y RESULTADOS}

\subsection{Densidad}

Se analiza la influencia de la presión sobre la densidad geométrica o bulk density de las piezas cilíndricas en verde, en seco y después de la cocción. Para las dos primeras los valores obtenidos apenas si varían con la presión de compactación, ver tabla 2 , y para la densidad tras al cocción, la figura 6 , muestra la variación de la densidad con la temperatura para cada presión de conformado, y de ella se deduce que la presión apenas influye sobre la densidad y que ésta aumenta con la temperatura, siempre que sea superior a $975^{\circ} \mathrm{C}$.

\subsection{Contracción de las piezas}

Las piezas al cocerlas sufren una contracción, y los valores obtenidos se reflejan en la figura 7 . La laboratory press which produced moulds of $40 \mathrm{~mm}$ diameter.

Different values of pressure were used: 15.6 MPa, 31.2 MPa, 46.8 MPa and 62.4 MPa.

Once the pieces were formed the density was determined and the mean value was found to be 1.7 g/c.c.

\subsection{Dried}

The drying took place in a furnace at a temperature of $110 \pm 10^{\circ} \mathrm{C}$ for 24 hours. During this time water was eliminated until it was of a dampness similar to the air that surrounded it.

\subsection{Boiling}

This is the most important part of the manufacturing process since it is here that the finished product possesses the required properties.

During boiling a series of parameters are imposed, such as: the maximum boiling temperatures, that according to the bibliography were: $900{ }^{\circ} \mathrm{C}, 950{ }^{\circ} \mathrm{C}$, $975{ }^{\circ} \mathrm{C}, 1.000{ }^{\circ} \mathrm{C}$ and $1.100{ }^{\circ} \mathrm{C}$; the time at the elected temperature, 2 hours, the oxidising atmosphere of the oven; the warming speed, $2{ }^{\circ} \mathrm{C} / \mathrm{min}$ and the cooling speed, $1{ }^{\circ} \mathrm{C} / \mathrm{min}$.

\section{ACCOMPLISHED TRIALS AND RESULTS}

\subsection{Density}

The influence of pressure on the crude density, dry density and density after boiling was analysed. For the first two the values obtained hardly varied with compressive pressure, table 2, and for the last one, figure 6, the density varies with boiling temperature for each pressure stated. From this it is deduced that the density increases with temperature, if temperature is higher than $975{ }^{\circ} \mathrm{C}$ and the pressure has hardly any influence.

\subsection{Contraction of the pieces}

The pieces, upon cooking, suffer contraction and the obtained values are reflected in the figure 7 . The 
TABLA 2 (TABLE 2)

Variación de la densidad con la presión de compactación

(Variation of density with compressive pressure)

\begin{tabular}{|c|c|c|}
\hline $\begin{array}{c}\text { Presión (MPa) } \\
\text { (Pressure (MPa)) }\end{array}$ & $\begin{array}{c}\text { Densidad en crudo }\left(\mathrm{g} / \mathrm{cm}^{3}\right) \\
\left.\text { (Crude density }\left(\mathrm{g} / \mathrm{cm}^{3}\right)\right)\end{array}$ & $\begin{array}{c}\text { Densidad en seco }\left(\mathrm{g} / \mathrm{cm}^{2}\right) \\
\left.\text { (Dry density }\left(\mathrm{g} / \mathrm{cm}^{3}\right)\right)\end{array}$ \\
\hline 15,6 & 1,73 & 1,64 \\
31,2 & 1,75 & 1,67 \\
46,8 & 1,75 & 1,68 \\
62,4 & 1,76 & 1,69 \\
\hline
\end{tabular}

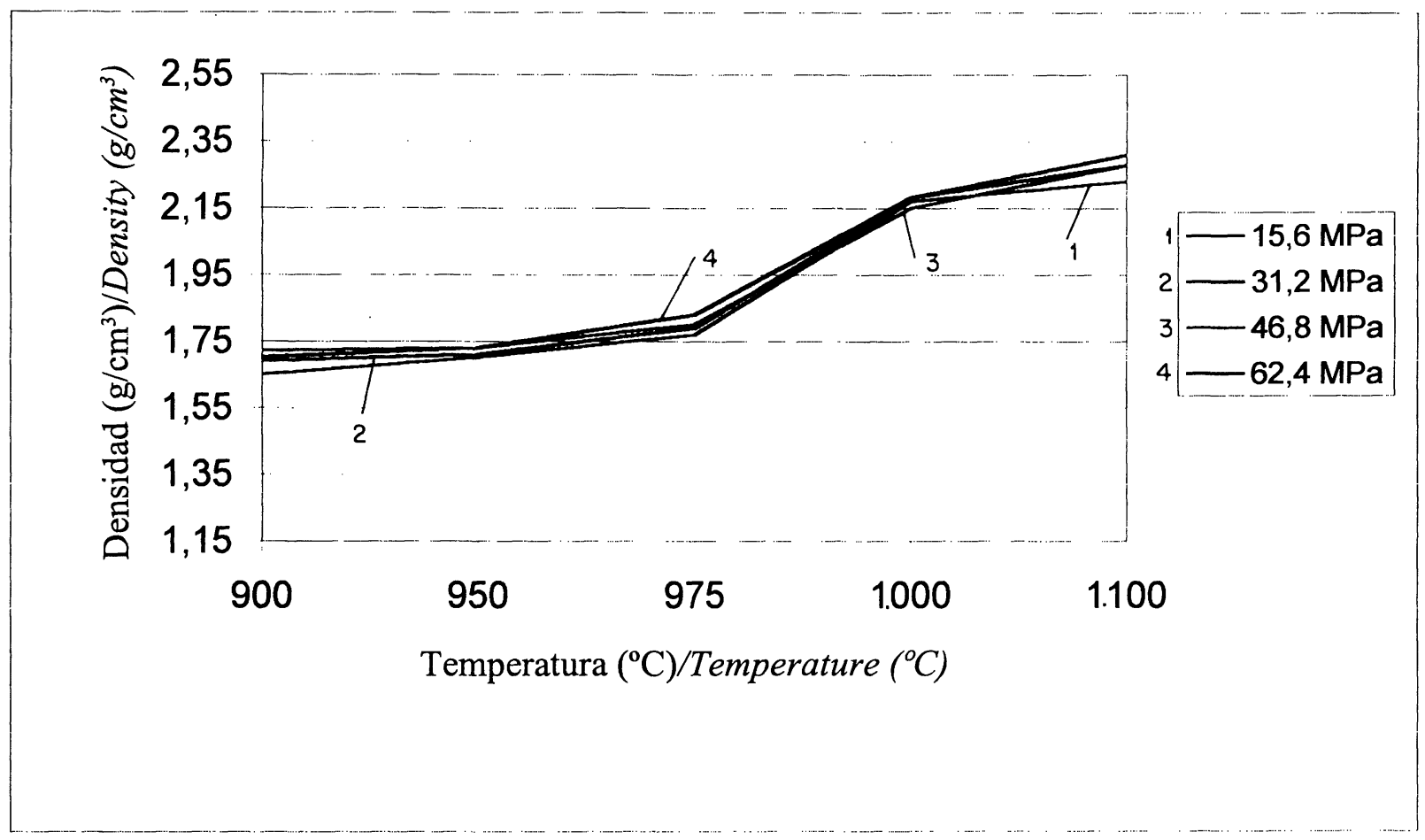

Figura 6.- Variación de la densidad con la temperatura.

Figure 6.- Variation of density with temperature.

contracción máxima se consigue al incrementar la temperatura de $975^{\circ} \mathrm{C}$ a $1.000^{\circ} \mathrm{C}$. Para una temperatura dada, la presión de conformado apenas si ejerce influencia en el valor de la contracción.

Si se observan las piezas cocidas a 1.000 y $1.100^{\circ} \mathrm{C}$ se puede detectar la gresificación que han experimentado.

\subsection{Succión de agua}

El ensayo de succión se ha realizado conforme a la Norma UNE 67-031-85 (10). En la figura 8 se maximum contraction occurs when the temperature is increased to between $975^{\circ} \mathrm{C}$ and $1.000^{\circ} \mathrm{C}$.

If the pieces are cooked to between $1.000^{\circ} \mathrm{C}$ and $1.100^{\circ} \mathrm{C}$ the vitrification they have experienced can be detected.

\subsection{Water suction}

The suction trial has been carried out according to the Norm UNE 67-031-85 specification (10). Figure 8 shows 


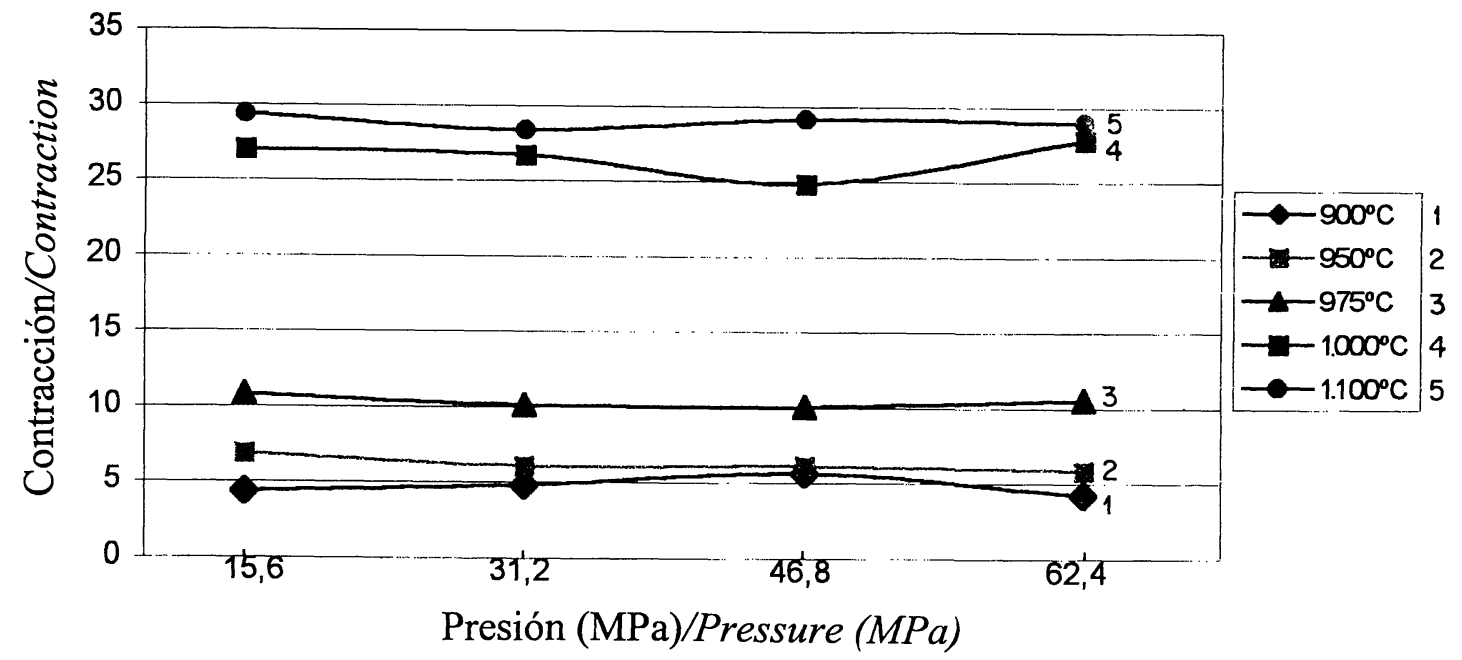

Figura 7.- Contracción de las piezas con la temperatura de cocción.

Figure 7.- Contraction of the pieces with the boiling temperature.

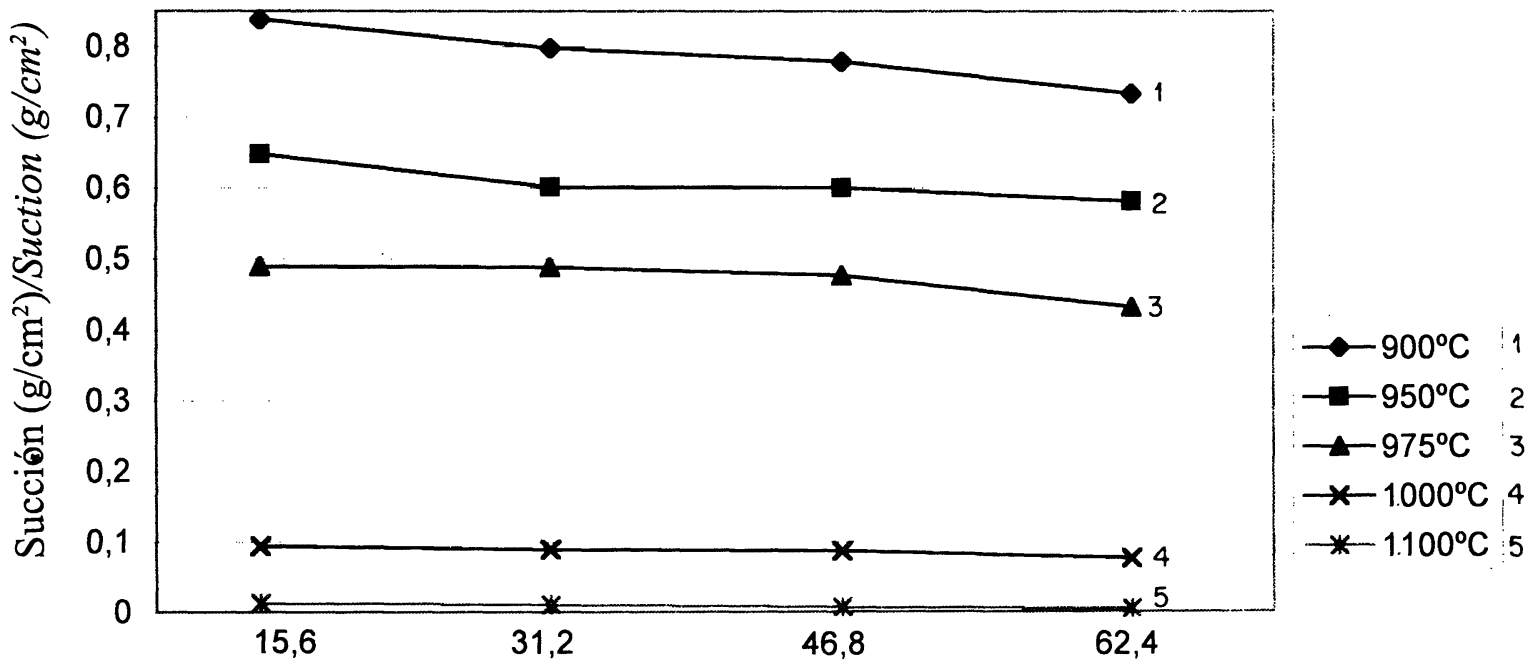

Presión (MPa)/Pressure (MPa)

Figura 8.- Variación de la succión con la presión.

Figure 8.- Variation of suction with the pressure.

representan los valores de succión frente a la presión de conformado para cada temperatura de cocción, del resultado del análisis de los mismos se deduce, que las piezas cocidas a temperaturas inferiores a $1.000^{\circ} \mathrm{C}$, quedan por encima del límite máximo de succión permitido por la norma; y las cocidas a temperaturas superiores a $1.000^{\circ} \mathrm{C}$ por debajo de los valores de referencia de deshidratación del mortero, no siendo necesario entonces humedecer estas piezas antes de su colocación (10). Sin embargo, las piezas cocidas a $1.100^{\circ} \mathrm{C}$ presentan una succión prácticamente nula, lo que tampoco es aconsejable, ya que no existiría una buena adherencia entre el ladrillo cerámico y el mortero de cemento. the suction values compared to pressure for each boiling temperature. On analysis of these results it can be seen that the pieces cooked at temperatures lower than $1.000{ }^{\circ} \mathrm{C}$ remain above the maximum suction limit permitted by the norm. Those pieces cooked at temperatures above $1.000{ }^{\circ} \mathrm{C}$ have values below the Norm and the dehydration reference value of the mortar. Due to this it is not necessary to wet the pieces before testing (10). However, the pieces cooked to $1.100{ }^{\circ} \mathrm{C}$ present a practically void suction, what either it is advisable, since would not exist a good adherence between the ceramic brick and the cement mortar. 
El incremento de la presión hace disminuir también, aunque de manera más discreta, la succión de las piezas.

\subsection{Absorción de agua}

La determinación del agua absorbida por las piezas cerámicas se ha realizado conforme a la Norma UNE $67-027-84$ (10). Los valores correspondientes a la absorción de las piezas se muestran en la figura $9 \mathrm{y}$ de los resultados obtenidos se deduce que la absorción de agua aumenta claramente al ir disminuyendo la temperatura de cocción. También existe una ligera disminución al ir aumentando la presión de prensado.

El valor límite establecido por la norma para la absorción de agua es el $22 \%$, por tanto, todas las piezas obtenidas cumplen la norma.

\subsection{Heladicidad}

Este ensayo permite determinar el comportamiento del ladrillo frente a los ciclos de hielo - deshielo. La determinación de la heladicidad en las piezas objeto de estudio, se ha hecho utilizando la Norma UNE 67$028-84$ (10). Los valores obtenidos quedan reflejados en las tabla 3.

Analizados los resultados se deduce que las piezas cocidas a temperatura inferiores a $1.000^{\circ} \mathrm{C}$, para todas las presiones de prensado, no superan las pruebas de heladicidad, ya que al proceder a una inspección ocular se observa la presencia de exfoliaciones, fisuras o desconchados. Por tanto, estas condiciones no son aptas para la fabricación de ladrillos cara vista. El comportamiento mejora a medida que aumenta la temperatura de cocción.
Also, an increase in pressure causes a reduction in the suction of the pieces.

\subsection{Water absorption}

The determination of the water absorbed by the ceramic pieces was carried out according to the Norm UNE 67 - $027-84$ (10). The absorption values for the pieces are shown in figure 9. From these results it can deduced that water absorption increases with a reduction in boiling temperature. Also, water absorption decreases with an increase in pressure.

The limit established by the norm for water absorption is $22 \%$ and all the obtained pieces fulfil the norm.

\subsection{Resistance to freezing}

This test attempts to determine the behaviour of the brick as compared to freeze- thaw cycles. The determination of the resistance to freezing in the pieces under study is carried out according to the Norm UNE $67-028-84$ (10). The obtained values can be seen in table 3 .

On analysis of the results it can be deduced that the pieces cooked at temperatures lower than $1.000{ }^{\circ} \mathrm{C}$, for all pressure used, do not pass the tests of Resistance to freezing and therefore these conditions cannot be used for the manufacture of the bricks. The behaviour improves with an increase in boiling temperature.

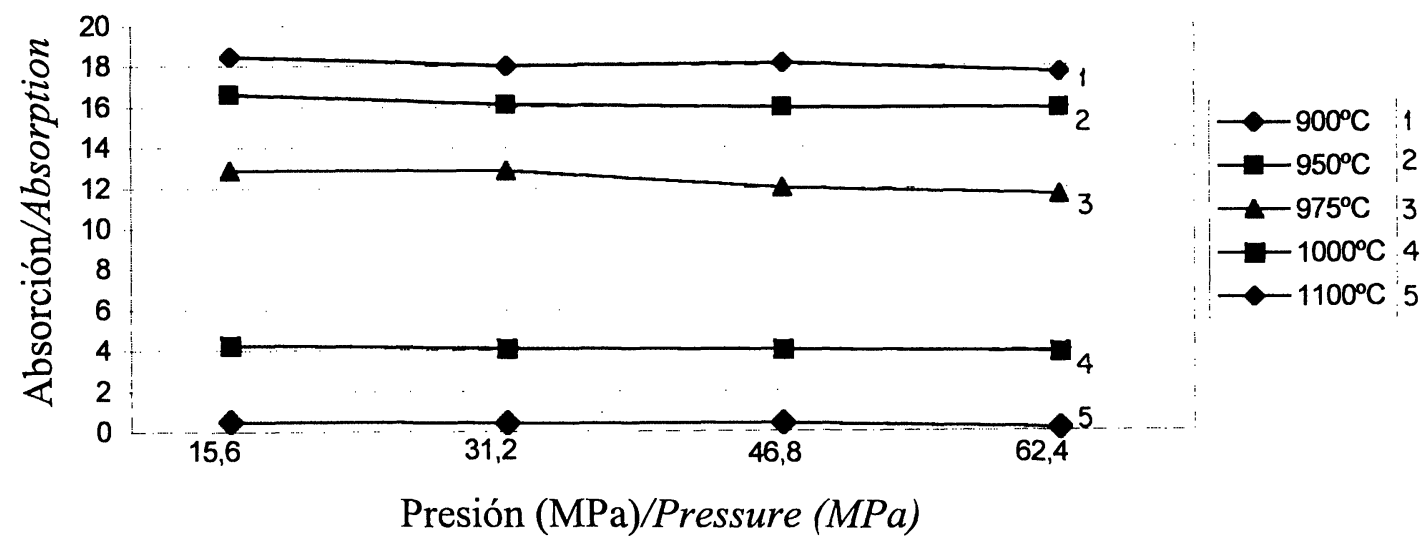

Figura 9.- Variación de la absorción con la presión.

Figure 9.- Variation of absorption with the pressure. 
TABLA 3 (TABLE 3)

Heladicidad a distintas presiones y temperaturas

(Resistance to freezing at different temperatures and pressures)

\begin{tabular}{|c|c|c|c|c|}
\hline \multicolumn{3}{|c|}{$\begin{array}{l}\text { Condiciones de análisis: (Analysis conditions): } \\
70 \mathrm{~g} \text { de cenizas volantes ( } 70 \mathrm{~g} \text { fly ashes) } \\
4,3 \mathrm{~g} \mathrm{de} \mathrm{H}_{2} \mathrm{O}\left(4.3 \mathrm{~g} \mathrm{H} \mathrm{H}_{2} \mathrm{O}\right) \\
0,7 \mathrm{~g} \text { de ligante }(0.7 \mathrm{~g} \text { blinder }) \\
1 \mathrm{~g} \text { lubricante }(1 \mathrm{~g} \text { lubricate) }\end{array}$} & \multicolumn{2}{|c|}{$\begin{array}{c}\text { Heladicidad } \\
\text { (Resistance to freezing) }\end{array}$} \\
\hline $\begin{array}{c}\text { Muestra } \\
\text { Sample }\end{array}$ & $\mathrm{T}\left({ }^{\circ} \mathrm{C}\right)$ & $\mathrm{P}(\mathrm{MPa})$ & $\begin{array}{c}\text { Superada } \\
\text { (Pass) }\end{array}$ & $\begin{array}{l}\text { No superada } \\
\quad(\text { Fail })\end{array}$ \\
\hline & & & & \\
\hline $\begin{array}{l}1 \\
2\end{array}$ & $\begin{array}{l}900 \\
900\end{array}$ & $\begin{array}{l}15,6 \\
31,2\end{array}$ & & $\begin{array}{l}X \\
X\end{array}$ \\
\hline 3 & 900 & 46,8 & & $\mathrm{X}$ \\
\hline 4 & 900 & 62,4 & & $\mathrm{X}$ \\
\hline 5 & 950 & 15,6 & & $\mathrm{X}$ \\
\hline 6 & 950 & 31,2 & & $\mathrm{X}$ \\
\hline 7 & 950 & 46,8 & & $\mathrm{X}$ \\
\hline 8 & 950 & 62,4 & & $\mathrm{X}$ \\
\hline 9 & 975 & 15,6 & & $\mathrm{X}$ \\
\hline 10 & 975 & 31,2 & & $\mathrm{X}$ \\
\hline 11 & 975 & 46,8 & & $\mathrm{X}$ \\
\hline 12 & 975 & 62,4 & & $\mathrm{X}$ \\
\hline 13 & 1.000 & 15,6 & $\mathrm{X}$ & \\
\hline 14 & 1.000 & 31,2 & $\mathrm{X}$ & \\
\hline 15 & 1.000 & 46,8 & $\mathrm{X}$ & \\
\hline •16 & 1.000 & 62,4 & $\mathrm{X}$ & \\
\hline 17 & 1.100 & 15,6 & $\mathrm{X}$ & \\
\hline 18 & 1.100 & 31,2 & $\mathrm{X}$ & \\
\hline 19 & 1.100 & 46,8 & $X$ & \\
\hline 20 & 1.100 & 62,4 & $\mathrm{X}$ & \\
\hline
\end{tabular}

\subsection{Eflorescencia}

Las eflorescencias son manchas superficiales en las caras de los ladrillos, generalmente blanquecinas, producidas por la cristalización de sales solubles, arrastradas por el agua hasta el exterior, en los ciclos de humectación-secado. La aparición de posibles manchas o simplemente la eflorescencia de las piezas, se evalúa mediante la Norma UNE 67-029-85 (10).

La tabla 4 muestra los resultados del ensayo. Las piezas cocidas a temperaturas inferiores a $1.000^{\circ} \mathrm{C}$, y para todas las presiones, todas ellas eflorescen, sin embargo, las cocidas a temperaturas superiores si pueden considerarse apropiadas o aptas para la fabricación de ladrillos cara vista, ya que presentan una ligera o mínima eflorescencia, la cual se consigue eliminar con un cepillado de la superficie de la pieza.

\subsection{Efflorescence}

The efflorescence is superficial stains in the faces of the bricks, generally whitish, produced by the crystallization of soluble salts, dragged by the water until the foreign, in the cycles of humidifying - dried. The possible appearance of whitish or simply efflorescent stains in the pieces, is evaluated through the Norm UNE 67 - 029 - 85 (10).

Table 4 shows the results of the trial. The pieces cooked at temperatures lower than $1000{ }^{\circ} \mathrm{C}$ are all efflorescent. However, those cooked at temperatures above $1.000^{\circ} \mathrm{C}$ can be considered appropriate for manufacture as they have light or minimal efflorescence which can be eliminated by brushing the surface of the piece. 
TABLA 4 (TABLE 4)

Eflorescencia a distintas temperaturas

(Efflorescence at different temperatures)

\begin{tabular}{|c|c|c|c|c|c|}
\hline \multicolumn{3}{|c|}{$\begin{array}{l}\text { Condiciones de análisis: (Analysis } \\
\text { conditions): } \\
70 \mathrm{~g} \text { de cenizas volantes (70 g fly ashes) } \\
4,3 \mathrm{~g} \text { de } \mathrm{H}_{2} \mathrm{O}\left(4.3 \mathrm{~g} \mathrm{H}_{2} \mathrm{O}\right) \\
0,7 \mathrm{~g} \text { de ligante }(0,7 \mathrm{~g} \text { blinder }) \\
1 \mathrm{~g} \text { de lubricante }(1 \mathrm{~g} \text { de lubricate) }\end{array}$} & \multicolumn{3}{|c|}{ Eflorescencia (Efflorescence) } \\
\hline $\begin{array}{l}\text { Muestra } \\
\text { Sample }\end{array}$ & $\mathrm{MPa}$ & $\mathrm{T}\left({ }^{\circ} \mathrm{C}\right)$ & $\begin{array}{c}\text { No } \\
\text { eflorescencia } \\
\quad(\text { No } \\
\text { efflorescence) })\end{array}$ & $\begin{array}{c}\text { Ligera } \\
\text { eflorescencia } \\
\text { (Lightly } \\
\text { efflorescence) }\end{array}$ & $\begin{array}{c}\text { Eflorescencia } \\
\text { (Efflorescence) }\end{array}$ \\
\hline & & & & & \\
\hline 2 & $\begin{array}{l}15,0 \\
31,2\end{array}$ & 900 & & & $\begin{array}{l}x \\
X\end{array}$ \\
\hline 3 & 46,8 & 900 & & & $X$ \\
\hline 4 & 62,4 & 900 & & & $X$ \\
\hline 5 & 15,6 & 950 & & & $X$ \\
\hline 6 & 31,2 & 950 & & & $X$ \\
\hline 7 & 46,8 & 950 & & & $\mathrm{X}$ \\
\hline 8 & 62,4 & 950 & & & $\mathrm{X}$ \\
\hline 9 & 15,6 & 975 & & & $\mathrm{X}$ \\
\hline 10 & 31,2 & 975 & & & $X$ \\
\hline 11 & 46,8 & 975 & & & $X$ \\
\hline 12 & 62,4 & 975 & & & $X$ \\
\hline 13 & 15,6 & 1.000 & & $X$ & \\
\hline 14 & 31,2 & 1.000 & & $\mathrm{X}$ & \\
\hline 15 & 46,8 & 1.000 & & $\mathrm{X}$ & \\
\hline 16 & 62,4 & 1.000 & & $X$ & \\
\hline 17 & 15,6 & 1.100 & & $\mathrm{X}$ & \\
\hline 18 & 31,2 & 1.100 & $\mathrm{X}$ & & \\
\hline 19 & 46,8 & 1.100 & & $X$ & \\
\hline 20 & 62,4 & 1.100 & & $X$ & \\
\hline
\end{tabular}
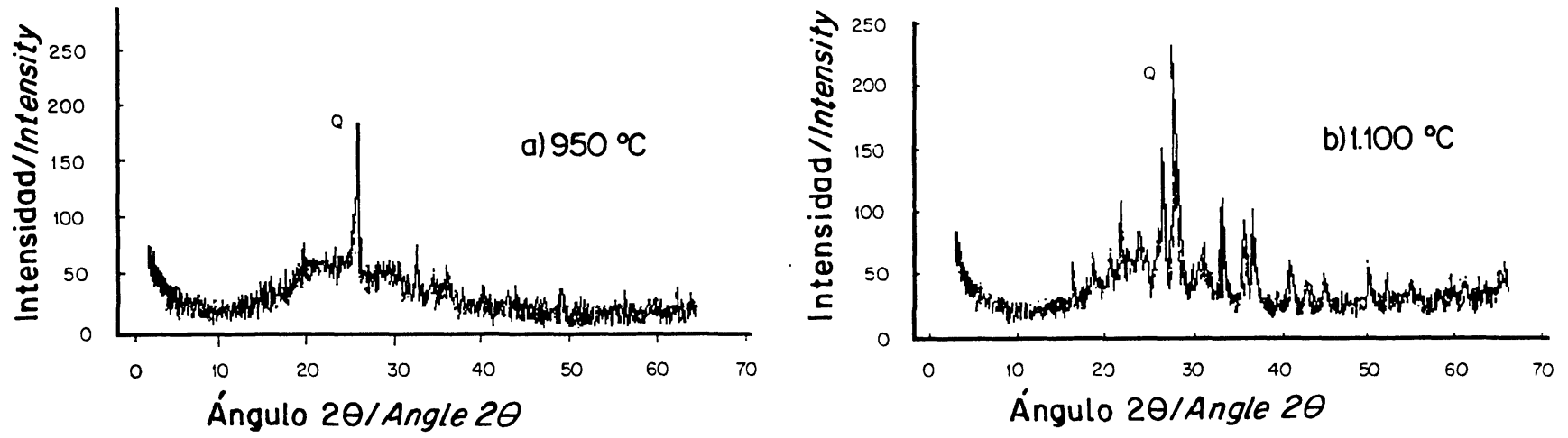

Figura 10.- Difractograma de la muestra cocida a diferentes temperaturas.

Figure 10.- Diffractograms of sample calcined at different temperatures. 
El diagrama de difracción de rayos $\mathrm{X}$ de las piezas cocidas a $950^{\circ} \mathrm{C}$, figura 10 (a), no refleja la presencia de sustancias cristalinas, a excepción del cuarzo, sin embargo, en la figura 10 (b), correspondiente a piezas cocidas a $1.100^{\circ} \mathrm{C}$ se observa la formación de una estructura cristalina. Esto podría explicar la desaparición de las eflorescencias a dicha temperatura.

\subsection{Resistencia a la compresión en frío}

Se entiende por resistencia a la compresión del ladrillo, la tensión de rotura determinada ejerciendo un esfuerzo uniaxil de compresión en dirección perpendicular a la tabla o cara mayor del ladrillo.

Los valores de compresión obtenidos al realizar el ensayo se reflejan en la figura 11, y de ella se deduce que la compresión en frío aumenta al aumentar la temperatura de cocción hasta $1.000^{\circ} \mathrm{C}$, para, luego, disminuir.

\section{CONCLUSIONES}

Las cenizas de la central térmica del Narcea tienen aplicación en la fabricación de hormigones y cementos debido a su carácter puzolánico, así como la fabricación de productos cerámicos.

Las condiciones óptimas de trabajo, proporcionan una composición de la pasta del $92 \%$ de cenizas volantes, $6 \%$ de humedad, $1 \%$ de ligante (dextrina blanca) y $1 \%$ de lubricante (polvos de talco), con una presión de conformado de 15,6 MPa y con una temperatura de cocción superior a $1.000^{\circ} \mathrm{C}$.
The $X$-rays diffraction of the pieces cooked at $950^{\circ} \mathrm{C}$ figure 10 (a), it does not reflect presence of crystalline substances, to exception of the quartz. However, in the figure 10 (b), corresponding to pieces cooked at $1.100{ }^{\circ} \mathrm{C}$ is observed the training of a crystalline structure. This would explain the disappearance of the efflorescence at such temperature.

\subsection{Compression in cold}

Resistance to compression of the brick is understood as the tension apparent at fracture after uniaxial compression perpendicular to the face of the brick has occurred.

The compression values obtained can be seen in figure 11. From this it can be deduced that the compression in cold increases upon an increase in boiling temperature up to $1.000{ }^{\circ} \mathrm{C}$ and then it reduces erratically.

\section{CONCLUSIONS}

Fly ash from the Narcea Power Plant has applications in the manufacture of cements and concrete due to its pozzolanic characteristics as well as in the production of ceramic products.

The optimum composition of the paste is $92 \%$ fly ash, $6 \%$ humidity, $1 \%$ binder (white dextrin) and $1 \%$ lubricant (talcum powders), with a pressure of 15.6 MPa and boiling temperature greater than $1000^{\circ} \mathrm{C}$.

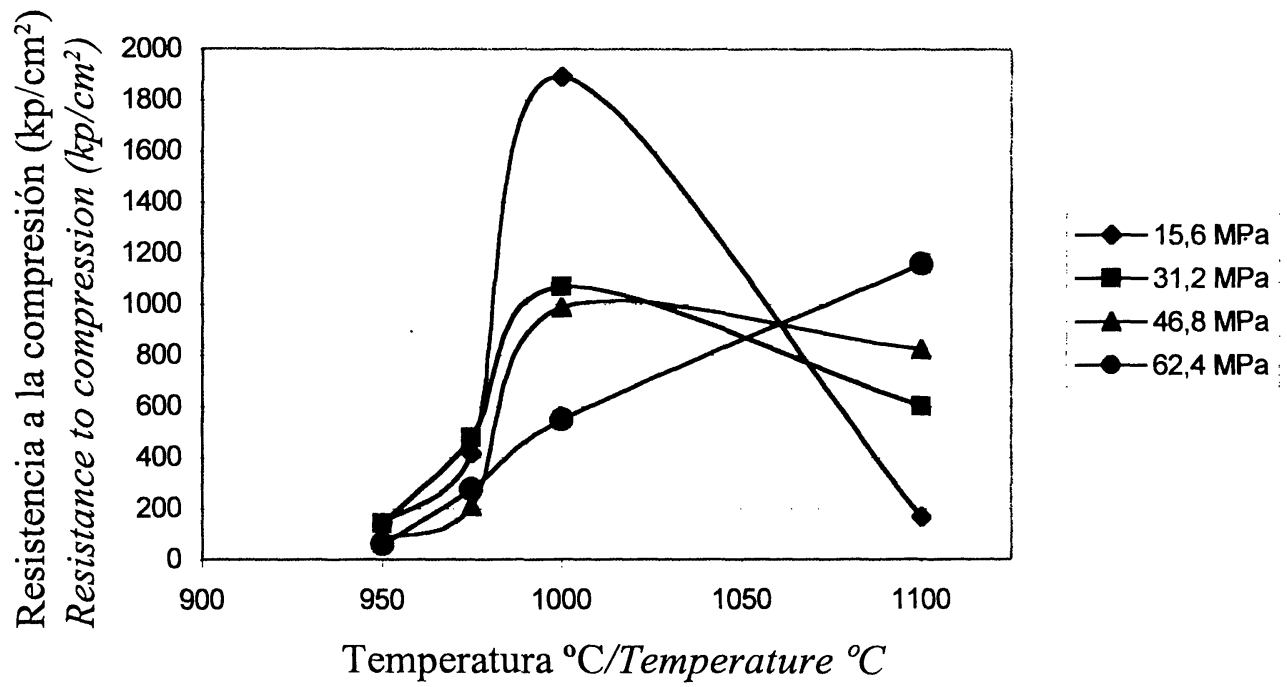

Figura 11.- Variación de la resistencia a la compresión con la temperatura de cocción.

Figure 11.- Variation of resistance to compression with the temperature of boiling. 
La resistencia a la compresión para las piezas cocidas, adquiere valores elevados cuando la temperatura de cocción es de $1.000^{\circ} \mathrm{C}$ o superior.

Las piezas cocidas a temperaturas superiores a $1.000^{\circ} \mathrm{C}$ obtienen la clasificación de no heladizas y no eflorescidas, presentando una ligera eflorescencia las cocidas a $1.000{ }^{\circ} \mathrm{C}$.

El ensayo de succión y absorción es superado tanto por las cocidas a $1.000^{\circ} \mathrm{C}$, con valores de $0,1 \mathrm{~g} / \mathrm{cm}^{2}$ y $4 \%$ respectivamente, como las de $1.100^{\circ} \mathrm{C}$.

La coloración rojiza y la estructura típica de un gres en las piezas, y sin presentar defectos que deterioren su aspecto de forma, hace que su durabilidad esté asegurada.
The resistance to the compression for cooked pieces reached high values when the temperature of cooking is of $1.000^{\circ} \mathrm{C}$ or superior.

The pieces cooked at temperatures above $1.000{ }^{\circ} \mathrm{C}$ did not obtain the classification for freezing and efflorescence, whilst the pieces cooked below $1.000{ }^{\circ} \mathrm{C}$ presented light efflorescence.

The suction and absorption trials were passed by the pieces cooked to $1.000{ }^{\circ} \mathrm{C}$, with a value of $0.1 \mathrm{~g} / \mathrm{cm}^{2}$ and $4 \%$ respectively as well as those cooked to $1.100{ }^{\circ} \mathrm{C}$.

The reddish colouration and typical structure of the vitreous pieces together with a lack of defects provides a long-lasting, durable material.

\section{BIBLIOGRAFÍA}

(1) C. FERNÁNDEZ, P. GARCÍA, J.J. DEL CAMPO, J. AYALA, F. BLANCO: " Use of Red Mud in construction materials". Light Metals99-106, 1996.

(2) M.P LUXÁN, M.I. SÁNCHEZ ROJAS, F. SORIA: Características de las cenizas volanes españolas. Materiales de Construcción, $\mathrm{n}^{\circ} 209,1988$.

(3) B. GUTIÉRREZ, C. PAZOS; J. COCA: Propiedades y aplicaciones de las cenizas volantes procedentes de Centrales Térmicas Energía,julio-agosto, 1991.

(4) A, JARRIGE: Les cendres volantes. Propietes. Applicattions Industrielles. Eyrolles, 1971.

(5) “Manual de Reutilización de Residuos de la industria Minera,Siderometalúrgicay Termoeléctrica”. Instituto TecnológicoGeo-Minero de España, 1995.

(6) M.C. ALONSO, M.P. LUXÁN: Aplicaciones de las cenizas volantes en el Campo de la Construcción. Experiencia Española. Instituto de Ciencias de la Construcción Eduardo Torroja, 1995.

(7) V.S. RAMACHANDRAN: “Concrete admixture Handbook". Noyes Publication, 1984.

(8) D. W. RICHERDSON: “ Moder Ceramic Engineering (2 ${ }^{\text {nd }}$ de.)”. Marcel Dekker, Inc. 1992.

(9) Tecnología Cerámica. Instituto de Química Técnica. Universidad de Valencia, 1985.

(10) Norma Básica de la Edificación. Ministerio de Obras Públicas y urbanismo. 